\title{
OVERVIEW AND COMPARISON OF PROFIT SHARING IN DIFFERENT BUSINESS COLLABORATION FORMS
}

\author{
Harald David Stein ${ }^{1}$, Romualdas Ginevičius ${ }^{2}$ \\ Vilnius Gediminas Technical University, Sauletekio al. 11, LT-10223 Vilnius, Lithuania \\ E-mail:1'hd.stein@web.de (corresponding author); ${ }^{2}$ romualdas.ginevicius@vgtu.lt
}

Received 10 September 2009; accepted 28 May 2010

\begin{abstract}
Growing international business has brought a variety of collaborative business structures. In the paper the problem of profit sharing is analyzed for diverse business collaboration forms. It is the purpose to give an overview of the main influence factors of profit sharing. The overview is limited to the most common collaboration forms: multinational company, franchise system, joint venture and cluster. It is shown that the factors that mostly influence the profit sharing are the input balance of every member, which is expressed as the aggregate of profit (financial benefit) and the technology (intangible benefit). Finally, the different business collaboration forms are compared.
\end{abstract}

Keywords: business collaboration, profit sharing, joint venture, multinational company, franchise, cluster.

Reference to this paper should be made as follows: Stein, H. D.; Ginevičius, R. 2010. Overview and comparison of profit sharing in different business collaboration forms, Journal of Business Economics and Management 11(3): 428-443.

\section{Introduction}

The profit sharing problem between two collaborative business units is an important question in theoretical and practical research. The profit is the crucial factor that determines the structure of business and the collaboration of business partners. Profit is not always the main target (collaborative business can also be formed with the goal to develop new technologies, to enter new markets, to reach particular strategic goals, etc.). Profit is not only the financial flow, which is transferred to collaborative business members. Profit in collaborative business may also include non-financial benefits.

In the different collaboration structure forms, the profit sharing decisions in may be based on various factors: contractual commitments, market relations, etc.

Problem. There is a variety of literature on financial decisions in collaborative business. In the profit sharing problem in collaborative business, usually the total profit maximization is investigated and the profit sharing among the members is neglected. Therefore, the paper formulates the question: "What are the main principles of profit sharing in the different forms of business collaboration?" 
The aim is to analyze the differences between the most common business collaboration forms with the purpose to determine the main principles and factors of collaborative business's profit sharing.

For the detailed analysis, four forms of business collaboration are chosen:

- multinational company,

- franchise system,

- joint venture and

- cluster.

They symbolize four different cases of collaboration, where the interior business units might have different proper interests. Different theoretical approaches are analysed. The article contains two main parts: literature analysis and research. In literature analysis, the state of the art of profit sharing is analyzed (Baumard 2008). The main sources for literature analysis are publications in scientific journals, which analyze managerial and financial problems of different business collaborations. In the research part the detailed analysis of profit sharing modes in multinational companies, franchise systems, joint ventures and clusters is presented, which is mostly based on Nakamura's (2005) formula for benefit sharing in a joint venture.

Methods of the research. The research of profit sharing in different business collaborations is based on comparative and systemic analysis of empirical studies of collaborative business's operation and financial aspects. The review of empirical studies spans from 1987 to 2007 and covers various aspects of collaborative business performance, but mostly concentrated on financial problems analysis. Namakura's formula is expanded and adopted to the other listed forms of business collaboration. Therefore two main factors are combined: financial and intangible benefit.

\section{Reasons for the cooperation between multinational companies}

Various authors (Buckley 2003; Contractor and Lorange 1988; Hopkins 1996; Nippa et al. 2007) regard the activity on foreign markets as an important reason for collaboration. Differences in

- culture,

- laws,

- politics, etc.

challenge companies in a way, that collaboration becomes a prerequisite for foreign market entries. Zentes (2005) presents several reasons for companies' collaboration in international business which is listed in table 1 .

\section{Profit sharing modelling in joint ventures, franchise systems, multinational companies and clusters}

\subsection{Profit sharing in joint ventures}

Shenkar and Zeira (1987) and Nippa et al. (2007) describe joint ventures as separate legal 
Table 1. Reasons for companies' collaboration

\begin{tabular}{l|l}
\hline Reason & Comment \\
$\begin{array}{l}\text { Transaction } \\
\text { costs economics }\end{array}$ & $\begin{array}{l}\text { Transaction costs are the economic analogy to "friction" in physics. Each } \\
\text { business transaction leads to costs. Collaborative structures can be organized } \\
\text { over markets or hierarchically. The criterion for the establishment of } \\
\text { collaborative structures is the minimization of the transaction costs. }\end{array}$ \\
\hline $\begin{array}{l}\text { Resources- } \\
\text { based view }\end{array}$ & $\begin{array}{l}\text { From the viewpoint of resources-based performance, companies are treated } \\
\text { as interdependent bundles of technology and competences. The focus is on } \\
\text { reaching an optimal access to scarce resources, either inside the collaborative } \\
\text { structure or from external sources. }\end{array}$ \\
\hline Strategic choice & $\begin{array}{l}\text { Collaboration is established on the basis of strategic analysis. The consequences } \\
\text { are predicted of establishing or not establishing collaboration. }\end{array}$ \\
\hline $\begin{array}{l}\text { Interests of } \\
\text { shareholders }\end{array}$ & $\begin{array}{l}\text { It is presumed that such relationships are established that are required by } \\
\text { shareholders and their particular interests. }\end{array}$ \\
\hline $\begin{array}{l}\text { Interest for } \\
\text { learning }\end{array}$ & $\begin{array}{l}\text { This theory is based on the idea that companies are collaborating because of the } \\
\text { need of getting more experience from the partners. }\end{array}$ \\
\hline $\begin{array}{l}\text { Institutional } \\
\text { dependence }\end{array}$ & $\begin{array}{l}\text { This reason for collaboration is originated from company's goal to look for } \\
\text { legal alliance with other organizations. The alliance in this case must be based } \\
\text { on strategically primary elements in the context of development guidelines }\end{array}$ \\
\hline
\end{tabular}

organizational entities partially held by parent firms originating from different countries. Joint ventures may be (Freshfields Bruckhaus Deringer 2001):

- a collaboration on a joint research project,

- a consortium to finance and carry out an infrastructure project,

- a multiparty start-up venture to develop and exploit the benefits of new technologies, - a collaboration with a local partner to carry on business in an 'emerging market',

- a full-scale international merger of existing businesses into a jointly owned corporate group.

Joint ventures always face the problem of profit sharing between collaborative business units, because these units are individual structures with no hierarchical relations between them. After Das and Teng (2000), Hausbald and Hege (2003) and Nakamura (2005), the problem of profit sharing in joint ventures can be focused in a conceptual way on two critical factors: sharing of risks and benefits by the partners (Demange and Wooders 2005; Gueguen 2009).

Usually, the creation and the performance of joint ventures is connected with risks (Das and Teng 2000). Potential problems may include (Freshfields Bruckhaus Deringer 2001):

- differences in culture,

- slower decision-making processes,

- different business objectives or

- the ways of solving disagreements.

Firstly, a big joint venture may be the industry leader and this ensures the possibilities to control industry's development, including the evaluation of standards, the spread in coherent industries or the speed of industry growth. 
Secondly, a large joint venture may have tools of impact on political decisions concerning the state economics. This enables joint ventures in some cases to participate in solving priority questions in economical development. On the other hand, such a possibility is connected with risks: the parent companies may have different strategic goals and for this reason the collaboration may be used as the tool for selfish ambitions.

The inputs and risks should be distributed thoroughly between the joint venture partners. contribution consists not only of financial input but also of intangibles, which are hard to measure (Besanko et al. 2009; Šelih et al. 2008; Zavadskas and Turskis 2008).

As it can be seen in Figure 1, the initial contribution is the main factor for profit sharing. This means that the assessment of the initial contribution must cover all tangibles and intangibles inputs and this is supposed to be the base for joint venture's equity sharing between the partners (Ginevičius et al. 2008a; Sivilevičius et al. 2008).

Each partner may have a different size of ownership in the joint venture, but the initial contribution of all partners must be equal. In order to equilibrate the initial contribution, the additional forms of contribution are used, which are often expressed in the form of various intangibles, for example, "know-how", professional competence, etc.

In this way, as Juan et al. (2007) present, the final allocation of profits and losses in a joint venture is possible not in the initial period but only after a certain transition period.

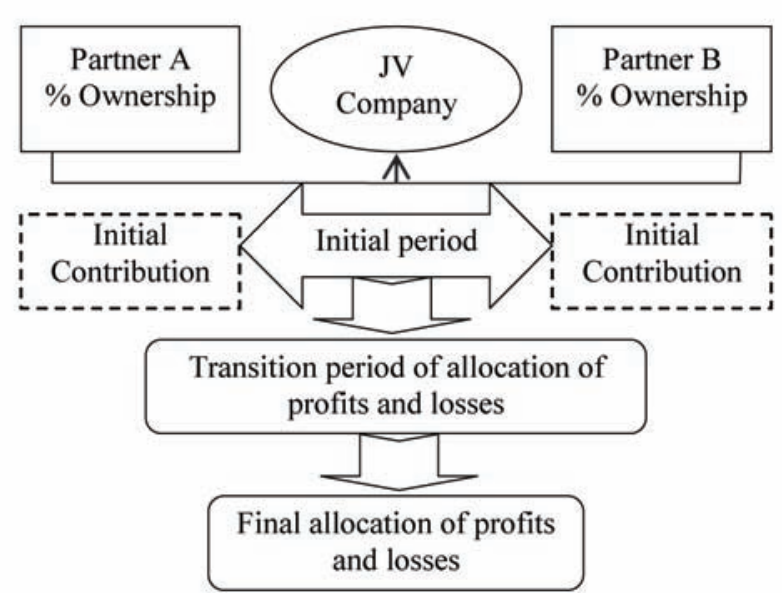

Fig. 1. The process of compensation and allocation of profit and losses in joint ventures (Juan et al. 2007)

Joint ventures exhibit the following intriguing ownership pattern (Hausbald and Hege 2003): the majority allocates equal or almost equal equity stakes to the parent firms. Large sample data indicates that about two-thirds of two-parent joint ventures have $50 \%-50 \%$ equity allocations, while up to $12 \%$ show $50.1 \%$ or $51 \%$ majority stakes. 
Nakamura (2005) presents a model of benefit allocation between joint venture partners in the case of assessment of technology spillover effect. In Nakamura's joint venture model there are 2 partners: of joint venture with two partners:

- a host partner with the material base for joint venture company formation and

- a foreign partner with financial, knowledge, technological, marketing, etc. resources.

The presumption is that the foreign partner's superior intangible assets such as technology, marketing, management and other skills are an integral source of their bargaining power in the negotiations with potential joint venture partners. This presumption shows that profit sharing in a joint venture is based not only on the equity of stakes, but also on various intangible assets (Zavadskas et al. 2008b; Sobotka and Rolak 2009; Ginevičius and Podvezko 2008a).

Nakamura explains his point of view using the analysis of joint venture's benefit sharing, which includes financial result and technological inputs (these are the main factors for a joint venture). As Nakamura states, the net expected benefits from the operation for both partners are given by the formulas 1 and 2:

Foreign partner:

$$
U_{F}=\beta Y+\beta g_{F} C_{J}-(1-\beta) C_{F} .
$$

Host partner:

$$
U_{J}=(1-\beta) Y+(1-\beta) g_{J} C_{F}-\beta C_{J},
$$

$U_{F}, U_{J}: \quad$ net expected benefits of foreign partner $F$ and host partner $J$,

$\beta$ : $\quad$ foreign partner's ownership share in joint venture,

$C_{F}, C_{J}: \quad$ technology cost of foreign partner $F$ and host partner $J$,

$g_{F}, g_{J}: \quad$ technology spillover level of foreign partner $F$ and host partner $J$,

$Y: \quad$ expected income of joint venture.

The given formula can be treated as the basis for profit sharing in a joint venture. Depending on the level of technology spillover, which is described as the additional benefit from sharing technological knowledge, the profit share is reallocated by giving the bigger share to the partner who receives less benefit from technology spillover (Stein 2010; Stein and Ginevičius 2010).

This conclusion appears from the modified Nakamura's (2005) formulas with the conclusion that joint venture is effective only in case of equal total benefit sharing between all partners. This can be expressed in the form, which is shown in formula 3:

$$
U_{F}=U_{J} \text { and } \beta Y+\beta g_{F} C_{J}-(1-\beta) C_{F}=(1-\beta) Y+(1-\beta) g_{J} C_{F}-\beta C_{j}
$$


As $\beta Y$ and $(1-\beta) Y$ is described as financial benefit and $\left(\beta g_{F} C_{J}-(1-\beta) C_{F}\right)$ and $\left((1-\beta) g_{J} C_{F}-\beta C_{J}\right)$ as technological benefit, it is clear that bigger technological benefit conditions lower financial benefit.In other words this equality can be expressed in such a way: the partner whose technology input is bigger, expects to receive a higher financial benefit (i.e. bigger profit share), and the partner whose technology input is smaller expects to compensate the smaller profit share by bigger technology spillover (Ginevičius and $\mathrm{Zu}$ brecovas 2009). The described benefit allocation between joint venture partners is valid not only in the case of technology spillover (Arieli 2008; Guan et al. 2009; Zavadskas et al. 2008a). This model can be adopted for the allocation of knowledge, experience, brand's value, etc.

\subsection{Profit sharing in a franchise system}

The profit allocation in franchise systems is similar: bigger spillover of intangibles for franchisee means bigger franchise usage fee. This model is based on the comparison of different governance levels of franchised intangibles. It is shown in figure 2.

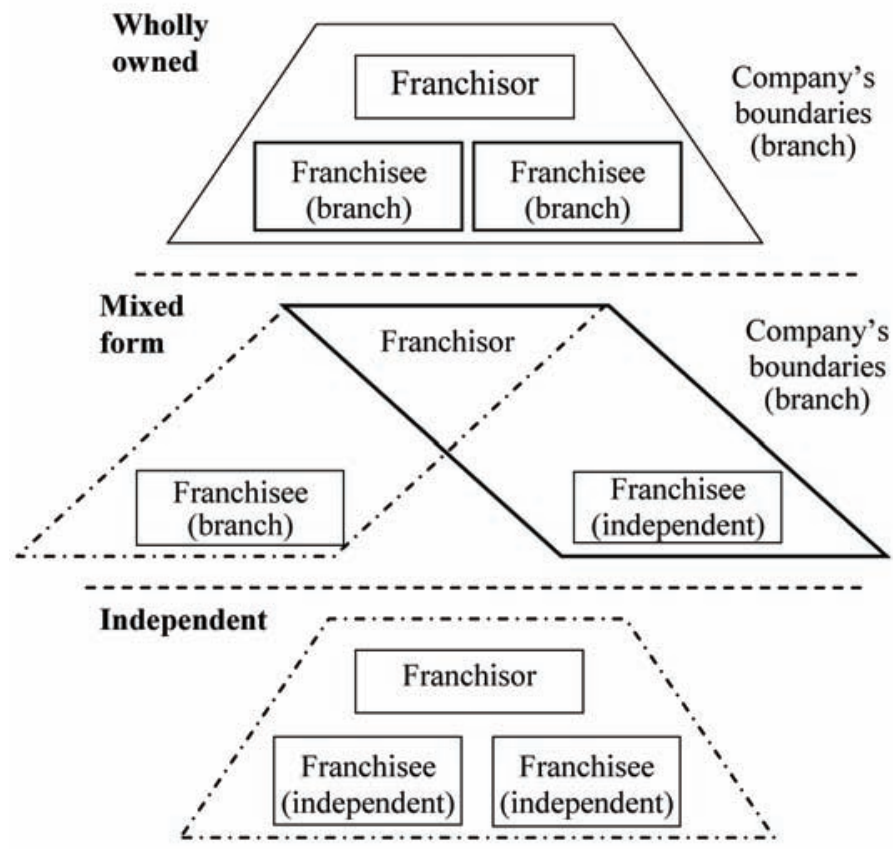

Fig. 2. Governance structure alternatives in franchising (made by author in accordance to Hendrikse and Jiang (2005))

The first case (wholly owned structure) is (Hendrikse and Jiang 2005; Ginevičius and Krivka 2008) the model of multinational company's profit sharing. The central unit 
(here: franchisor) is responsible for all kinds of inputs for efficient branches' functioning. It takes all the benefits from the system with no need to coordinate the central unit's interests with branches' interests. The profit sharing depends on the harmonization of both units interests.

The best way to represent the profit share problem in franchise system is to analyze the mixed form, where two types of subsidiaries are combined in one system:

- wholly owned branches and

- independent franchisees (Hendrikse and Jiang 2005).

The mixed form in franchising is useful for the franchisor because it enables him to use the advantages of both the wholly owned and the wholly franchised modes. The plural form allows the total control of profit sharing in owned branches and the spillover of intangibles between franchisor and franchisee. Bradach (1998) examines complementarities between the company-owned and franchised units. He argues that the plural form may help franchise networks to overcome four strategic challenges (Ginevicius et al. 2007):

- Growth. Adding new franchised units may help franchisors to overcome growth constrains.

- Uniformity. Specific relations are created in franchising chains, where companyowned units and franchised units set performance benchmarks for each other.

- Local responsiveness, which is enhanced by the franchisee's local response to local customers and the market-pressure processes.

- System-wide adaptation to change. It is improved by the mutual learning process because plural form can generate more diverse ideas.

The model of benefits of technology spillovers in joint venture can be adopted to franchise systems. In the mixed form of franchising the total benefit that consists of financial and technology benefits, can be expressed in the form of the formulas 4 and 5:

Franchisor:

$$
U_{F R}=Y+\alpha g_{F R} C_{F E}-(1-\alpha) C_{F R}
$$

Franchisee:

$$
U_{F E}=-Y+(1-\alpha) g_{F E} C_{F R}-\alpha C_{F E}
$$

$U_{F R}, U_{F E}$ : $\quad$ net expected benefits of franchisor $F R$ and franchisee $F E$,

$\alpha: \quad$ the intensity of franchisor - franchisee collaboration,

$C_{F R}, C_{F E}: \quad$ technology costs of franchisor and franchisee,

$g_{F R}, g_{F E}: \quad$ technology spillover of franchisor and franchisee,

$Y: \quad$ determined franchise fee.

The main difference between benefit shares in joint venture and franchise system is the share of financial results (profit or losses). In joint ventures the financial result $\mathrm{Y}$ 
is shared between all partners in proportions of equity stakes or other defined measurement. In a franchise system Y represents the franchisee's financial commitment for franchisor (Simon 1994; Kajii et al. 2008; Ngo and Okura 2008).

The commitment in the formula above is described as the franchise fee, the volume of money that the franchisee must pay for the usage of franchise benefits. As it was mentioned in the first chapter of the paper, this fee can be expressed in several ways - it can be fixed or be determined to some percents of the franchisee's income or profit (Bojar and Drelichowski 2008; Ginevičius et al. 2006).

In any case this financial benefit (Y) is a part of the total benefit from franchising only for the franchisor. The size of this fee depends on the spillover of technology between the franchisee and franchisor.

The bigger usage is that is received from franchisee, the lower is the expected financial fee. This is expressed in the formula 6, which represents the total benefit allocation principle in joint venture:

$$
U_{F R}=U_{F E} \text { and } Y+\alpha g_{F R} C_{F E}-(1-\alpha) C_{F R}=-Y+(1-\alpha) g_{F E} C_{F R}-\alpha C_{F E} \text {. }
$$

The formula shows that the bigger technology spillover is in the direction of franchisor and its owned branches, the lower is the franchise fee. A bigger network of owned branches leads to lower expected fees (Zavadskas and Vaidogas 2008).

The structural dependency between franchisor and franchisee is a way to show the possibilities to form different profit sharing agreements in a franchise system. The analysis of governance structure alternatives in franchising shows possible profit sharing modes in the context of choosing between franchise system and fully owned company (analogy to multinational company).

Despite this, it can be stated that every franchise system may result in an individual profit sharing system, which depends on several factors. Sydow (2000) presents the classification of franchise systems, using two dimensions (Figure 3):

- Strategic leadership, which shows the freedom of a franchisee to form his own business strategy and to develop long-run plan for strategic changes.

- Resources of the network leader, which characterizes the possibility for the franchisee to receive financial support from the franchisor for business development.

Sydow (2000) presents in his classification examples of franchise systems. "OBI" can be characterized as deeply integrated mode of franchising. The franchisor provides versatile financial support and requires directive management of the franchisee's performance strategy.

On the other side of this two-dimensional scale the example of "ComputerLand" is given, which is characterized as a franchise system with low financial support from the leader (franchisor) and with low impact on the franchisee's strategic decisions (Peldschus 2008, 2009). 


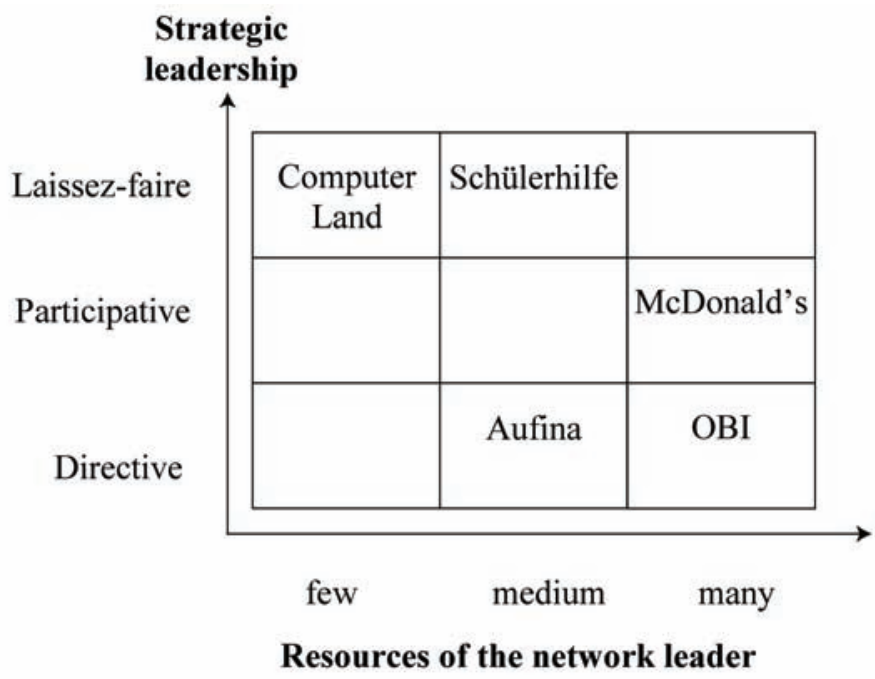

Fig. 3. Two-dimensional levels of franchise system's integrity (based on Sydow (2000))

\subsection{Profit sharing in a multinational company}

With the presumption that the total profit of a multinational company is allocated in the central unit, the profit sharing is expressed in the formulas 7 and 8 , where the subsidiary's performance factor is included:

Subsidiary:

$$
U_{S i}=\mu_{i} Y
$$

Central unit:

$$
U_{C U}=Y-\sum \mu_{i} Y
$$

$U_{S i}: \quad$ the part of total profit that subsidiary i receives,

$U_{C U}: \quad$ the part of total profit that central unit receives,

$Y: \quad \quad$ total profit in multinational company,

$\mu_{i}: \quad$ subsidiary's i development expectations.

In the presented formula, expectations symbolize the "expected perspective" of every subsidiary's development in the context of central unit's interests (Zavadskas et al. 2009). In this context the total profit of a multinational company can be divided in two different forms: the part of total profit that a central unit receives can be treated as dividends (the financial flows that shareholders receive) and the part of profit that 
subsidiaries receive can be treated as investment (Šijanec Zavrl et al. 2009; Ginevičius and Podvezko 2009).

The analysis of profit sharing decisions in a multinational company leads to the conclusion that (differently than in the case of a joint venture or franchise system) profit sharing can be based not on the benefit from technology spread, but on the expectations of the subsidiaries development (Ginevičius et al. 2008b; Hu et al. 2008).

\subsection{Profit sharing in a cluster}

In the case of a cluster there is a similar situation like with a multinational company (Rutkauskas 2008). However, in cluster the passive factor is financial flow, which is not shared directly between cluster members. The characteristic of a cluster are the tight collaborative relations between companies in the same industry with the purpose to create better conditions for knowledge and technology spread.

In this article knowledge and technical innovations are described as "technology". The profit flows in a cluster are related to technology sharing indirectly: companies that sell technologies may claim bigger income from other members of cluster and this situation leads to higher profitability of companies that develop technology faster. The assessment is made only for the technology share between two members of the cluster. The benefit of every company can be described in the form of formula 9:

$$
U_{C 1}=\alpha g_{C 1} C_{C 2}-(1-\alpha) C_{C 1},
$$

$U_{C 1}$ : the part of total profit that cluster i receives,

$\alpha: \quad$ collaboration intensity of cluster members 1 and 2,

$C_{C 1}, C_{C 2}$ : technology costs of cluster member 1 and 2 ,

$g_{C 1}$ : technology spillover level of cluster member 1.

According to this formula the balance in the cluster is guaranteed as follows: every member of the cluster must receive the same amount of technology as he tends to transfer to other members. If any member of the cluster transfers more technology than he receives, he has to get some additional value from his partners.

This additional value can be expressed in form of coefficient $Z_{i}$. It shows the additional value that cluster member i receives from technology sharing. Depending on the technology sharing ratio, coefficient $Z_{i}$ can be both positive (if a cluster member transfers more technology than he receives from the others) and negative (if a cluster member receives more technology then he transfers to others). In this case the benefit of an individual member of the cluster is expressed by the formulas 10 and 11 (Roy and Yami 2009): 


$$
U_{C 1}=\alpha g_{C 1} C_{C 2}-(1-\alpha) C_{C 1}+Z_{i}
$$

Considering the fact that a cluster usually contains more than two members, the benefit of individual member may be expressed:

$$
U_{C i}=\alpha \sum\left(g_{C j} C_{C j}\right)-(1-\alpha) C_{C 1}+\sum Z_{j}
$$

$\sum\left(g_{C j} C_{C j}\right)$ : technology transfer component from all cluster members, despite of member $i$,

$\sum Z_{j}$ : the expected additional value of all cluster members, despite of member $i$, to cover member $i$ 's value difference between the amount of technology transferred and technology received (Jakimavičius and Burinskienè 2009a).

The coefficient $Z_{i}$ in the formula characterizes the total additional value that the cluster member that transfers technology expects, except of the technology that the cluster member receives from other members. For this reason the additional value $Z_{i}$ can be treated as an indicator that shows the cluster members' income reallocation: a member of the cluster, who receives more technology than he transfers to the others, has to transfer more financial value from the supply chain to the other ones (Jakimavičius and Burinskienè 2009b).

\section{Profit sharing principles in different forms of business collaboration}

In Figure 4 the level of profit flow coordination in the presented business collaboration structures is presented. The figure shows that a multinational company is characterized by the biggest centralization level. This is reached by the total subordination of the subsidiaries under the central unit (Ginevičius and Podvezko 2008b).

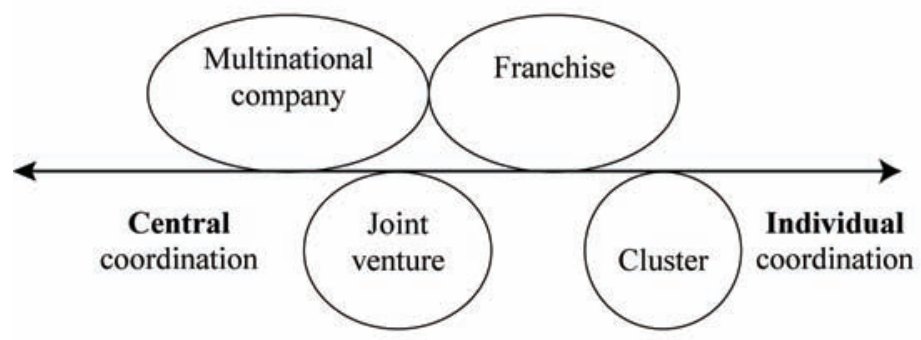

Fig. 4. The level of profit flow coordination in the different business collaboration structures

A lower level of centralization takes place in joint ventures where operations are performed by at least two partners, it particular cases also with equivalent coordination 
power. Those partners coordinate profit accumulation and allocation processes by making internal agreements. The clusters are the most individual and independent form of coordination. The main guidelines of profit sharing in the analyzed business collaboration structures are given in Table 2.

Table 2. Profit sharing in different business collaboration structures

\begin{tabular}{l|l}
\hline Business form & Characteristics \\
\hline Multinational company & $\begin{array}{l}\text { Profit remains in company, decisions about the profit sharing } \\
\text { are made in the central business unit }\end{array}$ \\
\hline Franchise system & $\begin{array}{l}\text { Franchiser receives contractual fee (periodical or non- } \\
\text { recurring; fixed or dependent on franchisee's income) } \\
\text { Franchisee receives profit after the fee is paid to franchiser }\end{array}$ \\
\hline Joint venture & $\begin{array}{l}\text { Profit of joint venture is shared between parent companies in } \\
\text { contractual proportion (similar to dividend sharing between } \\
\text { shareholders) }\end{array}$ \\
\hline Cluster & $\begin{array}{l}\text { Every member is responsible for his own profit. No standard } \\
\text { mode of profit sharing exists }\end{array}$ \\
\hline
\end{tabular}

The clearest situation concerning the profit sharing exists in multinational companies and clusters. Those two forms of collaboration may be treated as two different poles from the viewpoint of financial flows (profits and costs) coordination between collaborative business units:

- The structure of a multinational company is based on the existence of a central business unit, which has a control over all dependant units in different countries. That means that the total control of the subsidiaries' profit strictly defines possibilities of profit usage inside the subsidiary.

- The structure of a cluster is the opposite (in comparison to multinational companies). This leads to very Cluster's performance is based on the independent collaboration between individual business units where each business unit is self-supporting in profit creation and its sharing (no parent business structure exists).

The preliminary analysis of profit sharing peculiarities in different business collaboration structures shows that every business collaboration form has the specific problems. These problems appear because of the necessity to ensure the harmonization of interests of all participating business units.

\section{Conclusions}

1. An overview over the profit sharing in joint ventures, franchising systems, multinational companies and clusters has been given in this paper.

2. The functioning of the collaborative business is based on the compatibility of the collaborative business members' interests. Each member has to be satisfied with 
the proportion between his input and his benefit. For this reason the profit sharing problem is crucial between collaborative business members.

3. Profit sharing decisions in collaborative business are analyzed by Nakamura in the context of the following elements of benefit that a member of collaborative business receives:

- financial profit,

- technical innovations and

- knowledge and other intangibles, which are defined here as "technology".

Company's inputs in the business collaboration structure also include financial investments and the distribution of company's owned technology, which is transferred to other companies in the structure.

\section{References}

Arieli, D. 2008. Predictably Irrational. $1^{\text {st }}$ Ed. New York, NY: Harpercollins.

Baumard, P. 2008. Learning Strategies in Coopetitive Environments, in Le Roy, F.; Yami, Said (Ed.). Coopetition: Winning Strategy for the XXIst Century, 125-145.

Besanko, D.; Dranove, D.; Shanley, M. 2009. Economics of Strategy, 5th Ed. Hoboken, NJ: John Wiley \& Sons.

Bojar, W.; Drelichowski, L. 2008. Analysis of tendencies in agribusiness networking co-opetition in Poland and in the partner countries, Journal of Central European Agriculture 9(3): 445-456.

Bradach, J. L. 1998. Franchise Organisation. Harvard, USA: Harvard Business School Press.

Buckley, P. 2003. Globalization and the Multinational enterprise, The Oxford handbook of Strategy: Corporate Strategy 2: 209-225.

Contractor, F. J.; Lorange, P. 1988. Why should firms cooperate? in Cooperative Strategies in International Business, Lanham, MD, USA: Lexington, 3-54.

Das, T. K.; Teng, T. K. 2000. A resource-based theory of strategic alliances, Journal of Management 26(1): 31-61. doi:10.1016/S0149-2063(99)00037-9

Demange, G.; Wooders, M. 2005. Group Formation in Economics - Networks, Clubs and Coalitions. $1^{\text {st }}$ edition. Cambridge, UK: Cambridge University Press. doi:10.1017/CBO9780511614385

Freshfields Bruckhaus Deringer 2001. Joint ventures and alliances [online]. [Cited 07 July 2009]. Available from Internet: $<\mathrm{http} / / \mathrm{www}$.freshfields.com>.

Ginevičius, R.; Krivka, A. 2008. Application of game theory for duopoly market analysis, Journal of Business Economics and Management 9(3): 207-217. doi:10.3846/1611-1699.2008.9.207-217

Ginevičius, R.; Podvezko, V. 2008a. Multicriteria graphical-analytical evaluation of the financial state of construction enterprises, Technological and Economic Development of Economy 14(4): 452-461. doi:10.3846/1392-8619.2008.14.452-461

Ginevičius, R.; Podvezko, V. 2008b. Multicriteria evaluation of Lithuanian banks from the perspective of their reliability for clients, Journal of Business Economics and Management 9(4): 257-267. doi:10.3846/1611-1699.2008.9.257-267

Ginevičius, R.; Podvezko, V. 2009. Evaluating the changes in economic and social development of Lithuanian counties by multiple criteria methods, Technological and Economic Development of Economy 15(3): 418-436. doi:10.3846/1392-8619.2009.15.418-436

Ginevičius, R.; Zubrecovas, V. 2009. Selection of the optimal real estate investment project basing on multiple criteria evaluation using stochastic dimensions, Journal of Business Economics and 
Management 10(3): 261-270. doi:10.3846/1611-1699.2009.10.261-270

Ginevičius, R.; Butkevičius, A.; Podvezko, V. 2006. Complex evaluation of economic development of the Baltic States and Poland, Ekonomický Časopis 54(9): 918-930.

Ginevicius, R.; Podvezko, V.; Andruskevicius, A. 2007. Quantitative evaluation of building technology, International Journal of Technology Management 40(1-3): 192-214. doi:10.1504/IJTM.2007.013534

Ginevičius, R.; Podvezko, V.; Bruzgè, Š. 2008a. Evaluating the effect of state aid to business by multicriteria methods, Journal of Business Economics and Management 9(3): 167-180. doi:10.3846/1611-1699.2008.9.167-180

Ginevičius, R.; Podvezko, V.; Raslanas, S. 2008b. Evaluating the alternative solutions of wall insulation by multicriteria methods, Journal of Civil Engineering and Management 14(4): 217-226. doi:10.3846/1392-3730.2008.14.20

Guan, Z.; Yuan, D.; Zhang, H. 2009. Optimal and fair resource allocation for multiuser wireless multimedia transmissions, EURASIP Journal on Wireless Communications and Networking, 2009: Article ID 801613, 10 pages. doi:10.1155/2009/801613

Gueguen, G. 2009. Coopetition and business ecosystems in the information technology sector: the example of Intelligent Mobile Terminals, International Journal of Entrepreneurship and Small Business 8(1): 135-153. doi:10.1504/JJESB.2009.024109

Hausbald, R.; Hege, U. 2003. Ownership and control in joint ventures: theory and evidence, Discussion Paper Series No 4056, Centre for Economic Policy Research, London.

Hendrikse, G.; Jiang, T. 2005. Plural Form in Franchising: An Incomplete Contracting Approach, ERIM Report Series Research in Management December: 18-29.

Hopkins, D. M. 1996. International franchising: Standardization versus adaptation to cultural differences, Franchising Research: An International Journal 1(1): 15-24.

Hu, Y.; Houdet, J.; Duong, T. 2008. A multi-agent model of cooperative and competitive strategies in supply chain, Journal of Fudan University, Shanghai 9(1): 873-879.

Jakimavičius, M.; Burinskienè, M. 2009a. Assessment of Vilnius city development scenarios based on transport system modelling and multicriteria analysis, Journal of Civil Engineering and Management 15(4): 361-368. doi:10.3846/1392-3730.2009.15.361-368

Jakimavičius, M.; Burinskienè, M. 2009b. A GIS and multi-criteria-based analysis and ranking of transportation zones of Vilnius city, Technological and Economic Development of Economy 15(1): 39-48. doi:10.3846/1392-8619.2009.15.39-48

Juan, C.; Olmos, F.; Ashkeboussi, R. 2007. Compensation Options in Joint Ventures. A Real Options Approach, The Engineering Economist A Journal Devoted to the Problems of Capital Investment 52(1): 67-94. doi:10.1080/00137910601159839

Kajii, A.; Kojima, H.; Ui, T. 2008 [online]. The Myerson Value for Complete Coalition Systems, Faculty of Economics, Yokohama National University [cited 07 July 2009]. Available from Internet: $<$ http://www2.igss.ynu.ac.jp/ oui/netgame.pdf $>$.

Nakamura, M. 2005. Joint venture instability, learning and the relative bargaining power of the parent firms, International Business Review 14(4): 465-493. doi:10.1016/j.ibusrev.2005.04.003

Ngo, D.; Okura, M. 2008. Coopetition in a mixed duopoly market, Economics Bulletin 12(21): 1-9.

Nippa, M.; Beechler, S.; Klossek, A. 2007. Success factors for managing international joint ventures: a review and an integrative framework, Management and Organization Review 3(2): 277-310. doi:10.1111/j.1740-8784.2007.00067.x

Peldschus, F. 2008. Experience of the game theory application in construction management, Technological and Economic Development of Economy 14(4): 531-545.

doi:10.3846/1392-8619.2008.14.531-545 
Peldschus, F. 2009. The analysis of the quality of the results obtained with the methods of multi-criteria decisions, Technological and Economic Development of Economy 15(4): 580-592. doi:10.3846/1392-8619.2009.15.580-592

Roy, P.; Yami, S. 2009. Managing strategic innovation through coopetition, International Journal of Entrepreneurship and Small Business 8(1): 61-73. doi:10.1504/IJESB.2009.024105

Rutkauskas, A. 2008. On the sustainability of regional competitiveness, Technological and Economic Development of Economy 14(1): 89-99. doi:10.3846/2029-0187.2008.14.89-99

Šelih, J.; Kne, A.; Srdić, A.; Žura, M. 2008. Multiple-criteria decision support system in highway infrastructure management, Transport 23(4): 299-305. doi:10.3846/1648-4142.2008.23.299-305

Šijanec Zavrl, M.; Žarnić, R.; Šelih, J. 2009. Multicriterial sustainability assessment of residential buildings, Technological and Economic Development of Economy 15(4): 612-630.

doi:10.3846/1392-8619.2009.15.612-630

Simon, H. 1994. The Sciences of the Artificial, $3^{\text {rd }}$ edition. Cambridge, MA: The MIT Press.

Sivilevičius, H.; Zavadskas, E. K.; Turskis, Z. 2008. Quality attributes and complex assessment methodology of the asphalt mixing plant, The Baltic Journal of Road and Bridge Engineering 3(3): 161166. doi:10.3846/1822-427X.2008.3.161-166

Shenkar, O.; Zeira, Y. 1987. Human resources management in international joint ventures: directions for research, Academy of Management Review 12: 546-557. doi:10.2307/258520

Sobotka, A.; Rolak, Z. 2009. Multi-attribute analysis for the eco-energetic assessment of the building life cycle, Technological and Economic Development of Economy 15(4): 593-611.

doi:10.3846/1392-8619.2009.15.593-611

Stein, H. D. 2010. Allocation rules with outside option in cooperation games with time-inconsistency, Journal of Business Economics and Management 11(1): 56-96. doi:10.3846/jbem.2010.04

Stein, H. D.; Ginevičius, R. 2010. New co-opetition approach for supply chain applications and the implementation of a new allocation rule, in $6^{\text {th }}$ International Scientific Conference Business and Management, May 13-14, 2010, Vilnius, Lithuania. Vilnius: Technika, 1092-1099.

Sydow, J. 2000. Franchise systems as strategic networks: studying network leadership in the service sector, Asia Pacific Journal of Marketing and Logistics 10(2): 108-120. doi:10.1108/13555859810764490

Zavadskas, E. K.; Turskis, Z. 2008. A new logarithmic normalization method in games theory, Informatica 19(2): 303-314.

Zavadskas, E. K.; Vaidogas, E. R. 2008. Bayesian reasoning in managerial decisions on the choice of equipment for prevention of industrial accidents, Inzinerine Ekonomika - Engineering Economics (5): $32-40$.

Zavadskas, E. K.; Kaklauskas, A.; Turskis, Z.; Tamošaitienė, J. 2008a. Selection of the effective dwelling house walls by applying attributes values determined at intervals, Journal of Civil Engineering and Management 14(2): 85-93. doi:10.3846/1392-3730.2008.14.3

Zavadskas, E. K.; Turskis, Z.; Tamošaitienè, J. 2008b. Contractor selection of construction in a competitive environment, Journal of Business Economics and Management 9(3): 181-187.

doi:10.3846/1611-1699.2008.9.181-187

Zavadskas, E. K.; Andruskevicius, A.; Podvezko, V. 2009. Quantitative evaluation of the organisation of manufacturing and technological processes, International Journal of Technology Management 48(4): 544-556. doi:10.1504/IJTM.2009.026693

Zentes, J.; Swoboda, B.; Morschett, D. 2005. Kooperationen, Allianzen und Netzwerke [German: Cooperation, alliances and networks]. $1^{\text {st }}$ Ed., Wiesbaden: Gabler Verlag. 


\title{
PELNO PASIDALIJIMO SKIRTINGOMIS VERSLO STRUKTŪRŲ BENDRADARBIAVIMO FORMOMIS APŽVALGA IR PALYGINIMAS
}

\author{
H. D. Stein, R. Ginevičius
}

Santrauka

Augantis tarptautinis verslas praplètė verslo struktūrų bendradarbiavimo ịvairovę. Analizuojama pelno pasidalijimo problema skirtingoms bendradarbiavimo versle formoms. Vienas iš tikslų - pateikti pagrindinių pelno paskirstymą lemiančiu veiksnių apžvalgą. Šią apžvalgą dažniausiai riboja pasitaikančios bendradarbiavimo formos: tarptautinè įmonè, franšizès sistema, bendroji įmonè ir klasteris. Pastebèta, kad labiausiai pelno pasidalijimą lemia šie veiksniai: sąnaudų balansas kiekvienai narei, kuris išreiškiamas kaip agreguotas pelnas (finansinè nauda), ir technologijos (neapčiuopiama nauda). Palygintos skirtingos bendradarbiavimo formos.

Reikšminiai žodžiai: verslo struktūrų- bendradarbiavimas, pelno pasidalijimas, bendroji įmonè, tarptautinè i̇monè, franšizè, klasteris.

Harald David STEIN. Ph.D. student at the Faculty of Business Management at Vilnius Gediminas Technical University. He received his Diploma in Business Administration (Betriebswirtschaftslehre) at Humboldt-University in Berlin, Germany in 2006. The main subjects have been Business Informatics, Econometrics and International Management. His major research fields are the ambivalence of competition and cooperation (co-opetition) in business relationships and the implementation of microeconomic or game theoretic tool on referring problems. Furthermore, he has made research on future mobile Internet markets and the co-opetition of providers of different mobile access technologies. Currently, he works on the accomplishment of his Ph.D. thesis.

Romualdas GINEVIČIUS. Professor, Dr, Head of the Department of Enterprise Economics and Management, construction engineer and economist. The author of more than 350 research papers and over 20 scientific books; editor-in-chief of the 'Journal of Business Economics and Management' (located in ISI database 'Web of Science') and the journal 'Business: Theory and Practice'. Research interests: organization theory, complex quantitative evaluation of social processes and phenomena. 